\title{
Impact of exercise induced skeletal muscle strain on energy regulatory hormones of irisin and nesfatin-1 in sedentary males
}

\author{
Sedanter erkeklerde egzersize bağlı iskelet kası zorlanmasının enerji \\ düzenleyici hormonlar olan irisin ve nesfatin-1 üzerine olan etkileri
}

\author{
Seda UĞRAȘ1, Oğuz ÖZÇELiK
}

\begin{abstract}
Objective: Exercise important tool to regulate body energy metabolic system activity by increasing mechanical activity or hormonal effects. In this study, we aimed to examine effects of aerobic exercise on levels of irisin, which increases energy expenditure and nesfatin-1, which suppress energy intake and their connection with $\mathrm{CK}$, which reflects increased muscle injury.

Methods: Total of 30 healthy sedentary male preformed $30 \mathrm{~min}$ of aerobic running exercise work intensity associated with their anaerobic threshold. Blood samples were taken before and after exercise. Serum irisin nesfatin-1 and creatine kinase (CK) were analysed.

Results: During exercise serum irisin and CK levels increased in all subjects ( $16.4 \%$ and $25.7 \%$, respectively). Despite the mean values increased statistically significant, nesfatin-1 levels did not increased in all subjects (12.1\%). There was a positive statistically significant correlation between increase of irisin and CK levels.

Conclusion: Consequently, exercise induced skeletal muscle activity may cause increase in CK and irisin levels. Nesfatin-1 hormones may not seem to be exercise-induced hormone and did not correlate with
\end{abstract}

\section{ÖZET}

Amaç: Egzersiz, vücut enerji metabolik sistem aktivitesini, mekanik aktiviteyi veya hormonal etkileri artırarak düzenleyen önemli bir yöntemdir. Bu çalışmadaki amacımız aerobik egzersizin enerji tüketimini artıran irisin hormonu ve enerji alımını baskılayan nesfatin-1 hormonu üzerine etkilerini ve bunların kas hasarı artıșını yansıtan kreatin kinase (CK) ile ilișkisini incelemektir.

Yöntem: Toplam 30 sağlıklı, sedanter erkek katılımcıya anaerobik eşiklerinde 30 dakika aerobik koșu egzersizi uygulandı. Egzersiz öncesi ve sonrası kan örnekleri alındı. Serum irisin, nesfatin-1 ve CK analiz edildi.

Bulgular: Tüm katılımcılarda egzersiz süresince serum irisin ve CK düzeyleri artış gösterdi (\%16.4 ve \%25.7 sırası ile). Ortalama değerler istatistiksel olarak anlamlı artış göstermesine rağmen nesfatin-1 düzeyi tüm katılımcılarda artış göstermedi (\%12.1). Irisin ve CK seviyelerindeki artıșlar arasında pozitif yönde istatistiksel olarak anlamlı korelasyon sapyandı.

Sonuç: Egzersize bağlı iskelet kası aktivitesi CK ve irisin seviyelerinde artıșa neden olabilir. Nesfatin-1 egzersize bağlı hormon gibi görünmeyebilir ve artmıș kas aktivitesi ile korelasyon göstermemektedir. Orta

'Yozgat Bozok University, Faculty of Medicine, Department of Physiology, Yozgat

${ }^{2}$ Kastamonu University, Faculty of Medicine, Department of Physiology, Kastamonu

İletişim / Corresponding Author : Seda UĞRAŞ

Yozgat Bozok Üniversitesi Tip Fakültesi Yozgat - Türkiye

E-posta / E-mail : sedaugras@hotmail.com

Geliş Tarihi/Received : 01.05.2020

Kabul Tarihi / Accepted : 22.05.2020

DOI ID : 10.5505/TurkHijyen.2020.91328

Uğraș S, Özçelik 0 . Impact of exercise induced skeletal muscle strain on energy regulatory hormones of irisin and nesfatin-1 in sedentary males. Turk Hij Den Biyol Derg, 2020; 77(2): 227-232 
increased muscle activity. Moderate intensity aerobic exercise may provide beneficial effects on body energy regulatory systems by altering metabolic hormones.

Key Words: Irisin, nesfatin-1, creatine kinase, aerobic exercise

\section{INTRODUCTION}

Exercise has many important effects on improvement on fitness levels (1) and protects against many serious diseases including metabolic, cardiovascular and pulmonary (2). Exercise training is well known for its beneficial effects on metabolism and by increasing metabolic activity induced energy consumption (3).

In addition, in recent years, various hormones, secreted from skeletal muscle and adipose tissue, that regulating body energy balance have been introduced (4). Irisin is a newly described myokine secreted from skeletal muscle and increases energy expenditure by inducing the browning of white adipose tissue (5). Irisin may also improve glucose tolerance and reduce fasting insulin levels $(6,7)$.

Nesfatin-1, which was first introduce in 2006, is an important source of peripheral signal to brain and potent regulator of energy homeostasis by reducing food intake $(8,9)$. The effects of nesfatin- 1 in glucose control $(10,11)$, cardiovascular functions (12) and psychiatric disorders (13) has been shown.

The effects of exercise on these two hormones have becomes popular among scientist especially who interested with condition of energy regulation disorders. The studies conducted on irisin levels response to the exercise showed contradictory results some investigators showed increased irisin (14-16) some other did not found (17-19). In addition, the results of previous studies also revealed various conclusion concerning exercise and nesfatin-1 relationships (20-23).

To understand relationships between increased muscle activity and metabolic hormones of irisin and yoğunluktaki aerobik egzersiz metabolik hormonları değiștirerek vücut enerji düzenleyici sistemleri üzerinde faydalı etkiler sağlayabilir.

Anahtar Kelimeler: İrisin, nesfatin-1, kreatin kinaz, aerobik egzersiz

nesfatin-1, response of CK may provide important outcome. CK is widely used indirect biomarker of exercise induced muscle cell damage or disturbance (24-26). Thus, it is logical to expect aerobic exercise induced CK activity may have an effect on levels of irisin and nesfatin-1 hormones. We aimed to examine effects of aerobic exercise on levels of irisin, which increases energy expenditure and nesfatin-1, which suppress energy intake and their connection with CK, which reflects increased muscle injury.

\section{MATERIAL and METHOD}

Total of thirty healthy male aged between 18 to 25 years and body mass index between 18.5 to $25 \mathrm{~kg} /$ $\mathrm{m} 2$ were participated to this study. Body composition analyses were performed using BIA method (27). The subjects' physical characteristics are $20.8 \pm 2.5$ years, $179 \pm 10 \mathrm{~cm}, 65.2 \pm 9.1 \mathrm{~kg}$ and body mass index $20.3 \pm 2.3 \mathrm{~kg} / \mathrm{m} 2$. The ethical approvement for this study has been taken from local ethical committee. A signed informed consent was obtained from each subjects before participating to the study.

The subjects should be in sedentary condition and they had no daily or weekly regular exercise. The subjects should not smokers and taking no any drug, alcohol, caffeine or medication. They should be free of any metabolic cardiac or pulmonary system diseases. Before participating the study, the subjects were advised not to change their food intakes. The subjects were also instructed to avoid any physical activity at least 72 hours before the test. 
Following an overnight fasting, all subjects were performed a running exercise approximately 30 min after 5 minutes of warm up period in morning between 8:00 am to 9:00 am. The exercise intensity associated with anaerobic threshold reflecting moderate intensity and estimated approximately $65 \%$ of their predicted maximal heart rate (220-age) (28). Polar heart rate monitor used to control heart beat and prescribe to exercise intensity.

Venous blood samples were taken in to the aprotinin containing tube to avoid protein denaturation before and immediately after exercise. The samples centrifuged and serum was separated and stored at -80 C until analysis. Serum nesfatin-1 levels were measured using a commercial ELISA kit with a measurement interval of $31.2 \mathrm{pg} / \mathrm{ml}$ to 2000 $\mathrm{pg} / \mathrm{ml}$ (Boster Biological Technology Co Ltd, USA; Cat No: EK1138). Irisin level was determined by ELISA kit to have a sensitivity of $0.78 \mathrm{ng} / \mathrm{mL}$ (Phoenix Pharmaceuticals Inc, Burlingame, California, USA). $\mathrm{CK}$ analysis was performed using auto analyser.

Data are expressed as mean $( \pm S D)$. The Paired- $t$ test, which is a parametric comparison, was used to analyses the significance of basal and end exercise values. Pearson correlation analyses were performed between the parameters of $\mathrm{CK}$, irisin and nesfatin-1. A value of $p<0.05$ was accepted as statistically significant.

\section{RESULTS}

Exercise caused significant changes in serum levels of irisin in all subjects $(p<0.0001)$ (Table 1 ,
Figure 1). There was no systematic increase in all subject's nesfatin-1 levels, 6 subjects $(20 \%)$ showed decrease while 24 subjects $(80 \%)$ showed increase (Figure 1). However, in totally there was significant increase $(12.1 \%)$ in nesfatin-1 levels $(p=0.003)$ (Table 1). During exercise, systematic increase in CK levels were observed in all subjects $(\mathrm{p}<0.0001)$ (Table 1 , Figure 1). There was no correlation between increase of nesfatin-1 and CK levels. However, a positive significant correlation between change of irisin and CK levels were observed $R=0.63344(p<0.0001)$ (Figure 2).

\section{DISCUSSION}

In this study, moderate intensity walking exercise as determined from subjects' anaerobic threshold has significant effect on energy regulation hormones of irisin and nesfatin-1 levels. While exercise resulted in significant increase in irisin levels in all subjects, exercise had no impact on serum nesfatin-1 levels in all subjects (Figure 1). Despite the variation individually, nesfatin-1 levels (considering as a total mean values) were showed significant increase $(p=0.003)$. Increase of irisin (approximately 16.4\%) in response to the moderate intensity exercise are similar to the result of previous studies (29-31). Short term high intensity exercise also increases blood irisin levels (14). However, it has also been reported that exercise has no significant effects on irisin $(17,32)$.

We found a statistically significant positive correlation between change of irisin and CK levels (Figure 2). However, we did not find any statistically

Table 1. The mean (SD) values of irisin, nesfatin-1 and creatine kinase at the basal, at the end of the exercise and percent change during exercise. *reflects statistically significant difference

\begin{tabular}{|l|c|c|c|}
\hline No & Basal & End & \% change \\
\hline Irisin $(\mathrm{ng} / \mathrm{mL})$ & $108.7 \pm 7.6$ & $126.4 \pm 7.5$ & $16.4 \pm 5.1$ \\
\hline Nesfatin-1 $(\mathrm{pg} / \mathrm{mL})$ & $125.3 \pm 23.2$ & $139.4 \pm 31.2$ & $12.1 \pm 18.4$ \\
\hline CK $(\mathrm{U} / \mathrm{L})$ & $131.4 \pm 43.3$ & $165.5 \pm 55.1$ & $25.7 \pm 11.3$ \\
\hline
\end{tabular}




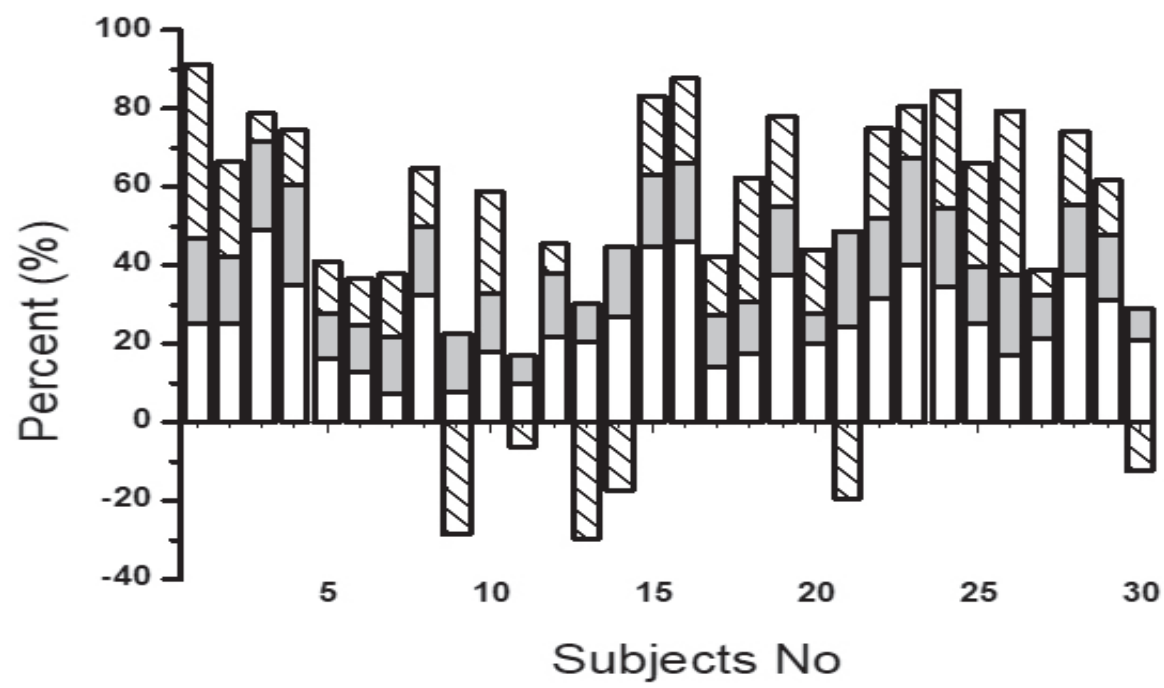

Figure 1. The percent change of irisin (white column), nesfatin-1 (grey colum) and creatine kinase (dashed column) response to the aerobic exercise for each individual subjects

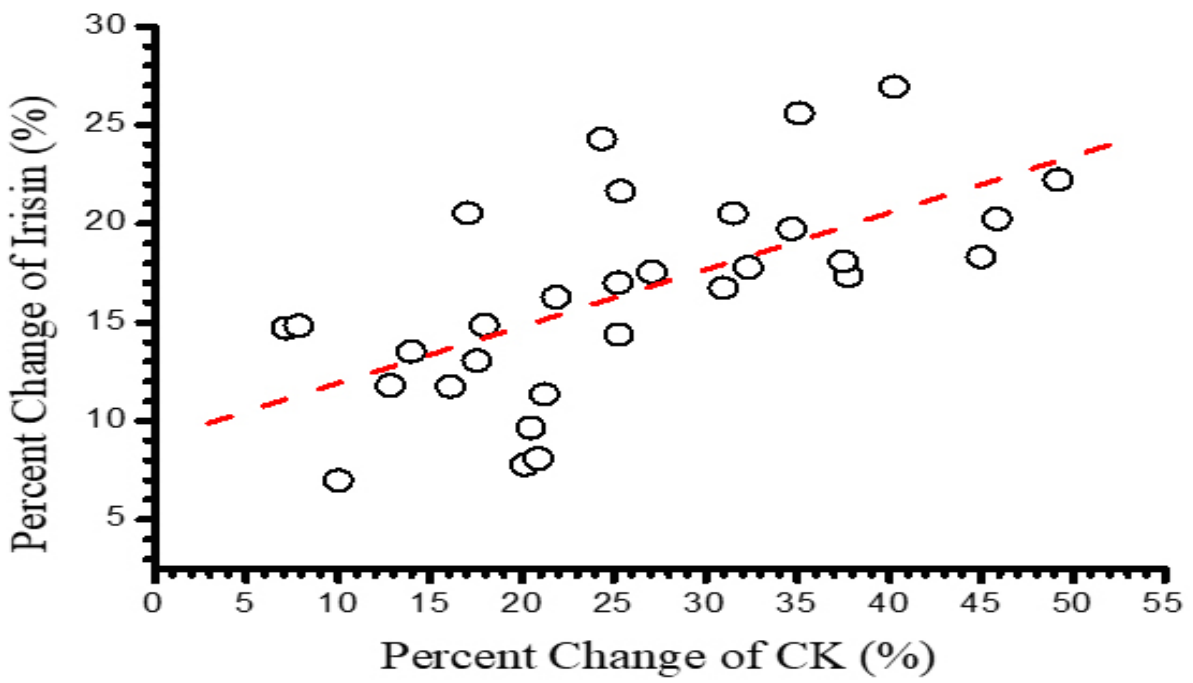

Figure 2. The correlation analysis between change of irisin and creatine kinase levels during aerobic exercise for each subjects

significant correlation between change of nesfatin-1 and $\mathrm{CK}$ during aerobic exercise. It is known that $\mathrm{CK}$ levels can be raised from the damage of the skeletal muscle tissue as a consequence of both metabolic and mechanical causes (25). Increase of CK during aerobic exercise may provide to obtain information on the state of exercising muscle (10). In a previous study performed in patient with metabolic syndrome showed that increase in CK levels by resistance exercise induced muscle damage evokes the release of irisin in to the circulation (29). However, it has been reported that exhaustive exercise causes increase in irisin levels without correlated CK levels (33). Increase in irisin levels in response to the elevated oxidative stress has been shown (34). Irisin is thought as a therapeutics agent for the metabolic diseases 
(35). Considering exercise and irisin response, there is various results, while it has been suggested that time of exercise may effect irisin levels (36) but other showed irisin levels increases without depending the time of exercise (37).

Nesfatin-1 also thought for strong agent for fighting against metabolic diseases especially diabetes and obesity $(10,37)$. However, there is no consensus with regarding nesfatin-1 and exercise relationships among the studies. Despite the opposite response among the subjects in this present study, we have found significant increase in nesfatin-1 levels. However, it has also been shown that acute or chronic exercise has no effects on nesfatin-1 levels $(10,23)$. In contrast, anaerobic exercise resulted significant increases in nesfatin-1 levels (21). In other study, nesfatin-1 levels increased in night time exercise (13).
The present study was limited by lack of comparability with a group of subjects with high and/or low fitness. It was not possible to discuss the influence of fitness status of subjects on CK, irisin and nesfatin-1 levels.

Consequently, this study shows that irisin is an exercise induced hormones and closely related with muscle activity as determined from increase of $\mathrm{CK}$ levels. However, despite the statistically significant increase in mean (SD) nesfatin-1 levels, some subjects showed decrease while other have increased nesfatin-1 levels.

The results of this study shows exercise is an effective way to regulate energy homeostasis by mechanical effects and may also enhance by an energy regulatory hormones.

\section{REFERENCES}

1. Wang Z, Tsujimoto T,Wakaba K, Mizushima R, Kobayashi H, Tanaka K. Associations of various exercise types with health-related physical fitness: Focus on physical fitness age. J Phys Fitness Sports Med, 2020; 9 (2): 75-2.

2. Nunan D, Mahtani KR, Roberts N, Heneghan C. Physical activity for the prevention and treatment of major chronic disease: an overview of systematic reviews. Syst Rev, 2013; 2: 56.

3. Ozcelik O, Ozkan Y, Algul S, Çolak R. Beneficial effects of training at the anaerobic threshold in addition to pharmacotherapy on weight loss, body composition, and exercise performance in women with obesity. Patient Prefer Adherence, 2015; 9: 999-1004.

4. Leal LG, Lopes MA, Batista ML JR. Physical exerciseinduced myokines and muscle-adipose tissue crosstalk: a review of current knowledge and the implications for health and metabolic diseases. Front Physiol, 2018; 9: 1307.

5. Bostrom P, Wu J, Jedrychowski MP, Korde A, Ye L, Lo JC, et al. A PGC1-alpha-dependent myokine that drives brown-fat-like development of white fat and thermogenesis. Nature, 2012; 481: 463-68.
6. Polyzos SA, Kountouras J, Shields K, Mantzoros CS. Irisin: a renaissance in metabolism? Metabolism, 2013; 62 (8): 1037-44.

7. Perakakis N, Triantafyllou GA, Fernández-Real JM, Huh JY, Park KH, Seufert J, et al. Physiology and role of irisin in glucose homeostasis. Nat Rev Endocrinol, 2017; 13 (6): 324-37.

8. Oh-I S, Shimizu H, Satoh T, Okada S, Adachi S, Inoue $\mathrm{K}$, et al. Identification of nesfatin-1 as a satiety molecule in the hypothala $\neg$ mus. Nature, 2006; 443: 709-12.

9. Stengel A, Tache Y. Nesfatin-1--role as possible new potent regulator of food intake. Regul Pept, 2010; 163 (1-3): 18-3.

10. Algul S, Ozkan Y, Ozcelik O. Serum nesfatin-1 levels in patients with different glucose tolerance levels. Physiol Res, 2016; 65 (6): 979-85.

11. Tekin T, Çiçek B, Konyalıgil N. Regulatory peptide nesfatin-1 and its relationship with metabolic syndrome. Eurasian J Med, 2019; 51 (3): 280-4.

12. Yosten GL, Samson WK. Nesfatin-1 exerts cardiovascular actions in brain: possible interaction with the central melanocortin system. Am J Physiol Regul Integr Comp Physiol, 2009; 297 (2): 330-6. 
13. Algul $S$, Ozcelik $O$. Evaluating the levels of nesfatin-1 and ghrelin hormones in patients with moderate an severe major depressive disorders. Psychiatry Investig, 2018; 15 (2): 214-8.

14. Daskalopoulou SS, Cooke AB, Gomez YH, Mutter AF, Filippaios A, Mesfum ET, et al. Plasma irisin levels progressively increase in response to increasing exercise workloads in young, healthy, active subjects. Eur J Endocrinol, 2014; 171 (3): 343-52.

15. Algul S, Ozdenk C, Ozcelik O. Variations in leptin, nesfatin-1 and irisin levels induced by aerobic exercise in young trained and untrained male subjects. Biol Sport, 2017; 34 (4): 339-44.

16. Nygaard H, Slettalokken G, Vegge G, Hollan I, Whist JE, Strand Tor, et al. Irisin in blood increases transiently after single sessions of intense endurance exercise and heavy strength training. Plos One, 2015; 10 (3): e0121367.

17. Kurdiova T, Balaz M, Mayer A, Maderova D, Belan V, Wolfrum $C$, et al. Exercise- mimicking treatment fails to increase Fndc 5 mRNA and irisin secretion in primary human myotubes. Peptides, 2014; 56: 1-7.

18. Raschke S, Elsen M, Gassenhuber H, Sommerfeld M, Schwahn U, Brockmann B, et al. Evidence against a beneficial effect of irisin in humans. Plos One, 2013; 8 (9): e73680.

19. Pekkala S, Wiklund PK, Hulmi JJ, Ahtiainen JP, Horttanainen $M$, Pöllänen $E$, et al. Are skeletal muscle FNDC5 gene expression and irisin release regulated by exercise and related to health? J Physiol, 2013; 591 (21): 5393-400.

20. Arıkan S. Effects of acute and chronic exercises on plasma nesfatin-1 levels in young adults. Cyprus J Med Sci, 2020; 5(1): 77-80.

21. Yazici AG. Relationship and interaction between anaerobic sports branches and serum nesfatin-1. Turk J Phys Med Rehab, 2015; 61: 234-40.

22. Ghanbari-Niaki A, Kraemer RR, Soltani R. Plasma nesfatin-1 and glucoregulatory hormone responses to two different anaerobic exercise sessions. Eur J Appl Physiol, 2010;110 (4): 863-8.

23. Algul S, Ozçelik O. Determination of the effects of acute aerobic exercise on nesfatin-1 levels. F.U Sag Bil Tip Derg, 2016; 30 (5): 8-16.

24. Koh TJ. Physiology and mechanisms of skeletal muscle damage. In: P.M. Tiidus (ed.) Skeletal muscle damage and repair. Human Kinetics Champaign IL, 2008; 3-12.

25. Brancaccio P, Maffulli N, Limongelli FM. Creatine kinase monitoring in sport medicine. Br Med Bull, 2007; 81 (82): 209-30.
26. Baird MF, Graham SM, Baker JS, Bickerstaff GF. Creatine-kinase- and exercise-relatedmuscle damage implications for muscle performance and recovery. J Nutr Metab, 2012; ID 960363: 13.

27. Kaya H, Özçelik O. Comparison of effectiveness of body mass index and bioelectric impedance analysis methods on body composition in subjects with different ages and sex. F.U Sag Bil Tip Derg, 2009; 23 (1): 1-5.

28. American College of Sports Medicine (ACSM). Guidelines for Exercise Testing and Prescription (9th ed.). Baltimore, MD: Lippincott, Williams and Wilkins, 2014.

29. Huh JY, Siopi A, Mougios V, Park KH, Mantzoros CS. Irisin in response to exercise in humans with and without metabolic syndrome. J Clin Endocrinol Metab, 2015; 100 (3): 453-7.

30. Kraemer RR, Shockett P, Webb ND, Shah U, Castracane VD. A transient elevated irisin blood concentration in response to prolonged, moderate aerobic exercise in young men and women. Horm Metab Res, 2014; 46 (2): 150-4.

31. Ozcelik O, Algul S, Yilmaz B. Nesfatin-1 and irisin levels in response to the soccer matches performed in morning, afternoon and at night in young trained male subjects. Cell Mol Biol (Noisy-le-Grand, France), 2018; 64 (10): 130-3.

32. Ozbay S, Ulupınar S, Şebin E, Altınkaynak K. Acute and chronic effects of aerobic exercise on serum irisin, adropin, and cholesterol levels in the winter season: indoor training versus outdoor training. Chin J Physiol, 2020; 63 (1): 21-6.

33. Qiu S, Bosnyák E, Treff G, Steinacker JM, Nieß AM, Krüger K, et al. Acute exercise-ınduced ırisin release in healthy adults: associations with training status and exercise mode. Eur J Sport Sci, 2018; 18 (9): 1226-33.

34. Ugras S, Algul S. Effects of aerobic exercise induced metabolic and cardiac stress on risin levels in trained subjects. J Med Bozok, 2020; 10 (1): 186-9.

35. Spiegelman BM. Banting lecture 2012: regulation of adipogenesis: toward new therapeutics for metabolic disease. Diabetes, 2013; 62 (6): 1774-82.

36. Winn NC, Grunewald ZI, Liu Y, Heden TD, Nyhoff LM, Kanaley JA. Plasma irisin modestly increases during moderate and highintensity afternoon exercise in obese females. Plos One, 2017; 12:e0170690.

37. Ozcelik O, Algul S, Deniz M, Baydas F, Tan F. Sabah ve gece yapilan aerobik egzersizin antrenmanlı deneklerde serum irisin düzeyine etkilerinin belirlenmesi. Genel Tip Dergisi, 2017; 27 (1): 1-5.

38. Algul S, Ozçelik O. A new promising pepdide for obesity treatment: Nesfatin-1. FU Sag Bil Tip Derg, 2012; 26: 143-8. 